\title{
AVALIAÇÃO DE MÉTODOS PARA ARMAZENAMENTO DE TECIDOS FOLIARES E OBTENÇÃO DE DNA EM CINCO ESPÉCIES DE BROMELIACEAE
}

\author{
Aléxia Gonçalves Pereira ${ }^{1}$ \\ Alessandra Abreu Rodrigues Vieira² \\ Lucimara Cruz de Souza ${ }^{3}$ \\ Adelson Lemes da Silva Junior ${ }^{4}$ \\ Kelmer Mozer Moro ${ }^{5}$ \\ Mariana Cruz de Souza ${ }^{6}$
}

Fábio Demolinari de Miranda ${ }^{7}$

Resumo: Realizaram-se testes comparativos utilizando diferentes metodologias de conservação de material foliar coletado de cinco espécies de Bromeliaceae, visando a obtenção de DNA de alta qualidade que possibilitasse estudos com marcadores moleculares. A qualidade do DNA extraído foi avaliada através de dois métodos: análise da pureza e quantificação em NanoDrop® por e ensaios utilizando três marcadores ISSR. Os resultados revelaram que, todos os métodos disponibilizaram material de qualidade. Entretanto, a obtenção de macerado a partir de folhas de Bromeliaceae liofilizadas demandam de tempo e esforço por parte do manipulador, sendo indicada a aplicação de metodologias de congelamento com nitrogênio líquido, uma vez que produz material de boa qualidade possibilitando a obtenção de resultados nítidos na técnica de eletroforese.

Palavras-chave: Liofilização; Otimização de protocolo; ISSR; Quantificação de DNA; Conservação do DNA.

\footnotetext{
1 Graduação em Ciências Biológicas Bacharelado/Universidade Federal do Espírito Santo, Brasil. E-mail: alexiagp@gmail.com.

2 Pós-Graduação em Genética e Melhoramento/Universidade Federal do Espírito Santo, Brasil. E-mail: abreuepires@gmail.com.

3 Pós-Graduação em Genética e Melhoramento/Universidade Federal do Espírito Santo, Brasil. E-mail: lucimaracruz15@hotmail.com.

4 Pós-Graduação em Genética e Melhoramento/Universidade Federal do Espírito Santo, Brasil. E-mail: adelsonlemes@yahoo.com.br.

5 Graduação em Ciências Biológicas Bacharelado/Universidade Federal do Espírito Santo, Brasil. E-mail: kelmer.moro@gmail.com.

${ }^{6}$ Graduação em Agronomia/Universidade Federal do Espírito Santo, Brasil. E-mail: scruz.mariana@gmail.com.

7 Professor do Departamento de Biologia/Universidade Federal do Espírito Santo, Brasil. E-mail: fademolinari@yahoo.com.br.
} 